has united practically all producers and manufacturers, makes it possible to put regularly at the disposal of malarial areas large quantities of quinine for longer periods. Obstacles to the use of this superabundance of the Java cinchona estates are largely financial and technical. Disbursements for defence in all countries cripple other projects, including health or hygienic measures. In addition, malaria control with quinine requires an efficient administrative machine for the distribution of the drug under medical supervision. For mass treatment of malaria, quinine is unlikely to be replaced by other cinchona alkaloids or synthetic drugs.

\section{United States National Museum}

THE report of the United States National Museum for 1939 is a stimulating document, particularly in the evidence it contains of widespread activities in exploration and field work. No fewer than fifteen expeditions or trips were made, mostly to chosen localities in the United States, but also to regions ranging from the South Pacific Ocean to Alaska and West Greenland, for the collection of data or specimens bearing upon archæology, anthropology, stratigraphic palæontology, and animal and plant distribution. Specially noteworthy seem to have been the results of Dr. Hrdlička's tenth visit to Alaska and the Aleutian Islands, where many skeletons and artefacts of a pre-Aleut stock were collected. The educational activities of the Museum, apart from the usual special exhibits, fourteen of which ran almost continuously throughout the year, include an admirable scheme for the allocation of duplicates to schools and other institutions, which benefited to the extent of 3,293 specimens. Exchanges involved the dispersal of 13,362 specimens, and it is gratifying to note that the British Museum (Natural History) was a very active partner in this useful form of scientific cooperation. The catalogues of the various departments now record the collections as containing more than 16 million specimens. The popularity of the exhibited galleries is indicated by the total of $2,233,345$ individuals who visited the various Museum buildings, and a glance at the monthly lists shows that the holiday periods of April and August afford welcome opportunities to visitors. The cost of running the Museum during the year was 771,880 dollars.

\section{Rabies Treatment in Southern India}

THE annual report of the director, Lieut.-Colonel Iyengar, for 1938 of the Pasteur Institute of Southern India, Coonoor, surveys the anti-rabic treatment given at the Institute and the subsidiary treatment centres during the year. A total of 12,396 persons were treated at the Institute and centres during the year, with twenty-one deaths, a mortality rate of 0.17 per cent. Animals to the number of 561 were also treated. Paris fixed virus, now in its 1,011th passage, was used in the preparation of the vaccine, which consisted of a 5 per cent carbolized sheepbrain suspension prepared by Semple's method. Under research work, experiments were carried out on the cultivation of the rabies virus. Attempts to culture the rabies virus on the chorio-allantoic membrane of the developing hen's egg, so useful for propagation of some viruses, were unsuccessful. In media containing chick embryo brain, propagation of the virus was apparently attained, though the method does not promise to be of much practical importance.

\section{Medical Research in Egypt}

THE fifth annual report of the Research Institute and the Endemic Diseases Hospitals, Cairo, by the director, Dr. M. Khalil Bey, contains a summary of the reports of the scientific sections and the clinical reports, including investigations on Egyptian splenomegaly, anæmias and various parasitic affections. A report is also included of the work of the Khanka Malaria Research Station. This gives the results of a mosquito survey of the area, with the species of mosquitoes found, and a description of some of the preventive measures undertaken. These include drainage, filling up of water holes and clearance of water-weeds in places. Breeding places of mosquitoes are treated with Paris green when there are Anophelines only, or with mazout oil if Culex larvæ are also present. In future, the Institute will be named the "Fouad the First Institute and Hospital for Tropical Diseases".

\section{Bermuda Seismograph Station}

IT is reported in Earthquake Notes (11, No. 4 ; April 1940) that through the co-operative effort of the Bermuda authorities, the Woods Hole Oceanographic Institute, the United States Coast and Geodetic Survey and Dr. George P. Woollard of Princeton University, the second component of the Milne-Shaw seismograph at Bermuda has been installed, the first records being obtained on December 10, 1939. The significance of this station is not only that earthquakes in eastern North America and the West Indies will be located more accurately, but also satisfactory studies of wave transmission over all mid-Atlantic paths have become possible. The position of this St. Georges, Bermuda, meteorological and seismological station is latitude $32^{\circ} 22^{\prime} 47^{\prime \prime} \mathrm{N}$., longitude $64^{\circ} 40^{\wedge} 57^{\prime \prime} \mathrm{W}$., elevation $136 \mathrm{ft} . ; \mathrm{Mr}$. C. P. Bartram is in charge.

\section{British Empire Naturalists' Association}

THE British Empire Naturalists' Association announces the retirement of its honorary general secretary, Mrs. G. B. Thomason, which took place at the end of April after thirty-five years work. She is a niece of E. K. Robinson, who founded the B.E.N.A., and has been responsible for most of the routine business work of the Association. It is also announced that plans have been made to hold the usual B.E.N.A. summer gathering in the first fortnight of June, and the Ludlow district has been selected : local arrangements will be put in the hands of the Shropshire Branch, and, despite the War, the local interests of fauna, flora and scenery are hoped to attract a good attendance. 